\title{
STUDY OF LAND RESOURCES AT SIWA OASIS USING REMOTE SENSING AND GIS TECHNIQUEES
}

Thabet, M. A.*; A. A. Abdel Hady*; W. A. M. Abd El Kawy* and A. H. EL-Nahry**

* Soils Sci. Dept., Faculty of Agric., Cairo University ,Giza ,Egypt.

** National Authority For Remote Sensing and Space Science, Cairo, Egypt.

moham1988ed@yahoo.com

00201000910952 - 009647905121243

\begin{abstract}
The area under investigation bounded by $25^{\circ} 16^{\circ}-26^{\circ} 7^{-} \mathrm{E}$ and latitudes, $29^{\circ} 7^{\circ}-29^{\circ} 21^{\circ}$ $\mathrm{N}$; and extended for about $70 \mathrm{~km}$ in east-west direction, with a width of 7-10 km. The dominant texture class varied from sand, loamy sand, sandy loam; and silt loam. $\mathrm{pH}$ values ranged between 7.4 and 9.3. CaCo3 content ranged between 1.6 and $42.3 \%$. O M values varied from 0.1 and $2.6 \%$. Gypsum content ranged between 0.01 and $5.04 \%$. EC values varied from 0.5 and $98.3(\mathrm{ds} / \mathrm{m})$. The CEC values varied from 1.9 and $35.09(\mathrm{mq} / \mathrm{l})$. ESP values varied from 6.3 and $36.4 \%$. Nitrogen values varied from 11.1 and $55.9(\mathrm{ppm})$. Phosphorus values varied from 2.8 and $60.8(\mathrm{ppm})$. Potassium values varied from 186.6 and $933.1(\mathrm{ppm})$. Based on the american soil taxonomy-the soils were classified as Typic Torripsamments, Typic Psammaquents, Typic Haplosalids, Typic Aquisalids, Gypsic Haplosalids, Calcic Aquisalids, Typic Haplocalcids, Lithic Haplocalcids, and Duric Haplosalids. The soil capability varied from Good, Average, Low , and Extremely low. Soil suitability for alfalfa, green pepper, onion, maize, barley, sugar cane, tomato, wheat, and wheat ranged between marginal and unsuitable except for olives, and date palm, ranged between moderate and unsuitable.

Keywords: Soil capability, soil suitability, soils classified, Nitrogen, phosphorus, potassium.
\end{abstract}

\section{INTRODUCTION}

The Siwa Oasis occupies a large depression west of the western Egyptian desert (Map 1), approximately $300 \mathrm{Km}$ south from the Mediterranean coast in correspondence of the city of Marsa Matruh. The Siwa depression $\left(29^{\circ} 7^{\prime}-29^{\circ}\right.$ $21^{\prime} \mathrm{N}$ e $25^{\circ} 16^{\prime}-26^{\circ} 7^{\prime} \mathrm{s}$ ) roughly stretches from east to west for approximately $82 \mathrm{Km}$, with a width that varies between 9 and $28 \mathrm{Km}$, and a total area of about $2,950 \mathrm{~km}$. sq representing the ideal continuation towards west of the larger depression of Qattara ( Said, 1990). 


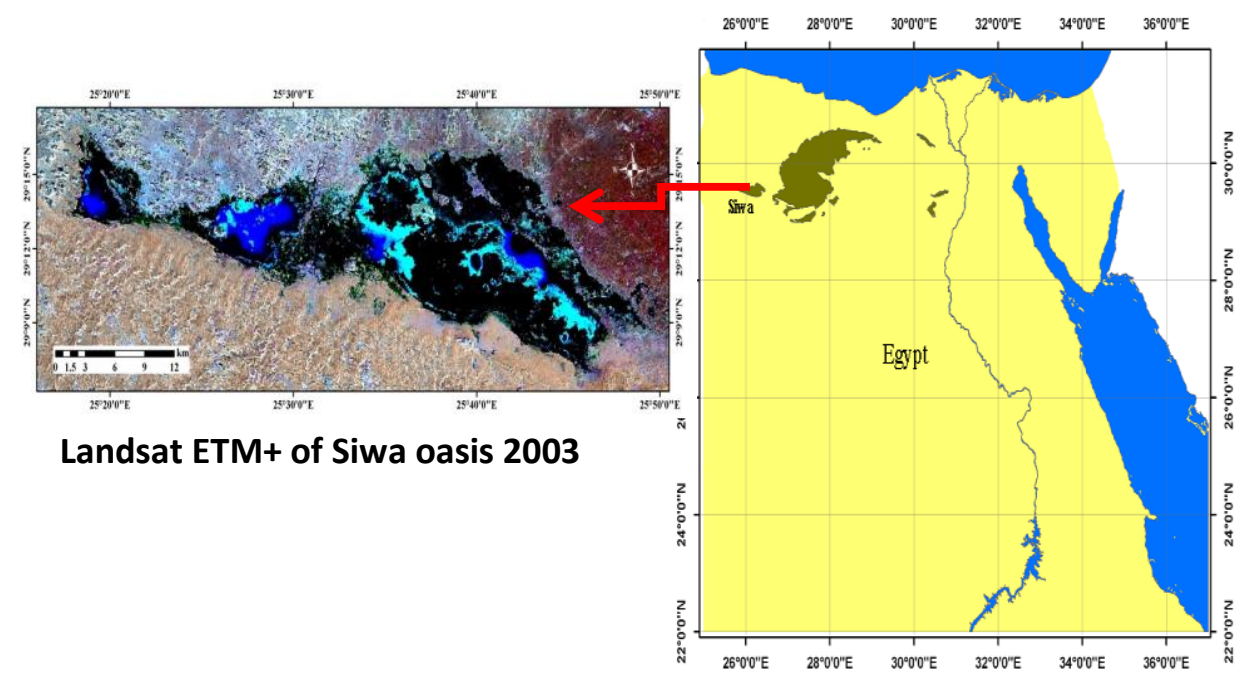

Map (1). Location of the study area

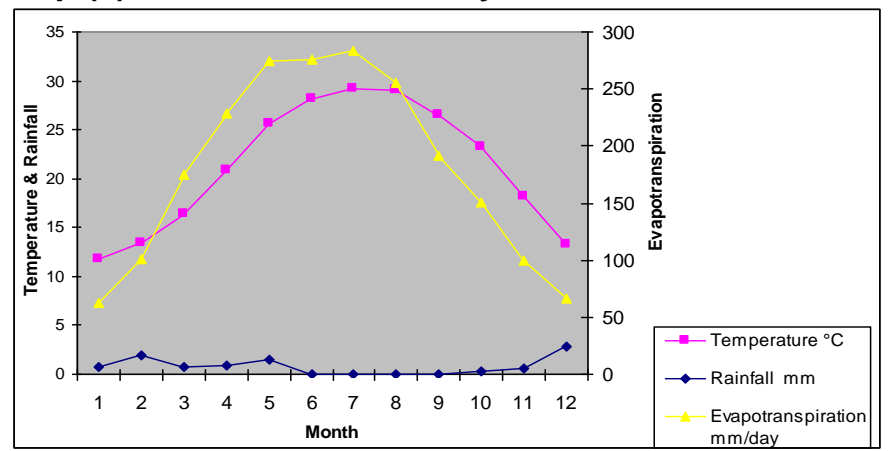

Figure (2) : climatology of studied area (Climatologically Normal for Egypt, 2011).

Abu Al-Izz (1999), and said (2000). The Stratography of the exposed rocks in Siwa depression from oldest to youngest are Middle Eocene, upper Eocene, Oligocene, Miocene, recent and sub-recent deposits. The Miocene deposits form the greater part of Siwa area, cover a large part of the depression floor, the entire northern scarp, and many hills of southern scarp, such as Gabal El-Dakrur. The Miocene section is approximately $120 \mathrm{~m}$ thick and divisible into lower unit of clastics and upper unit of solid limestone. The lower unit of clastics is of a wide distribution in the southern limits of the depression and within the depression. It consists of shales, sandstones and marl beds that are rich in fossiliferous; many of the shales are gypsiferous. The upper limestone unit is composed of coarse-grained-limestone beds with some marls. The recent and sub-recent deposits have accumulated along the southern limits of the depression, forming parallel north west-trending sand 
dunes, and salty soils with crusts on the surface that cover a large part of the depression floor.

According to Abu Al-Izz (1999), the geomorphologic features are very important in Siwa depression, and could be noted as follows: 1- The sea of sand: It occupies an area of about $500 \mathrm{~km}$ long by 160 to $180 \mathrm{~km}$ wide. The actual composition of this "sea" is waves of Seif dunes separated by wades. 2- The lakes: The most important lakes in Siwa depression are Al-Maraqui lake, Siwa lake, Khamisa lake, Al-Zeitun lake, and Other lakes: there are also great numbers of small lakes such as Al-Maasir, Tamira, Aghormi, each of these lakes has an area not more than hundreds of square meters. 3- The hills and mountains: The main hills are Um Al-Huwaymil, Qaret al-Hamra, Qaret al-Bayda and Qaret El-Gari. The main mountains are Gabal Siwa (38m), Gabal El-Mawta (42m), Gabal El-Kosha (36m), Gabal Aghormi (16m), Gabal El-Dakrur (88m), Gabal El-Girba (120m), Gabal El-Migahiz (100m), Gabal western Migahiz (120m), and Gabal Umm Hiyus (90m).

Abo-Ragab and Samy (2008), reported that to their studies on Siwa soils organic matter is mostly low owing to the prevailing climatic condition and ranged between 0.03 to $2.83 \%$. The low cation exchange capacity indicate that Siwa soils are relatively poor in organic matter content, and relatively low clay content, besides their high $\mathrm{CaCO}_{3}$ content. The CEC values of Siwa soils ranged between $4.0-25.2 \mathrm{cmol}_{\mathrm{C}} / \mathrm{kg}$ soil. Abd El-Samie (2000), reported that in the coarse clay fraction there were Kaolinite with some mixed-layer Montmorillonite - Illite and few quartz, while Smectite was abundant in the fine clay fraction. Omran (2002) defined 18 taxonomic units representing the soil mapping units in Siwa, which are belong to two orders, Entisols and Aridisols. Entisols include Torripsamments and Torriorthents. Aridisols include Haplocambids, Aquisalids, Haplosalids, Aquicambids, and Petrocalcids.

According to Fanous (1979) and Sherif (1979), there are native forage such as common sadge maishshear grass (Glodium Mariscus Cyperacoae), Camel thorne (A.maurorum Leguminosae) and matsedge (Juncus Arabicus) grown in some areas having relatively high water table. Also, native seeding date palms (Phoenix Dectylifera linn) are widely spread in Siwa oasis.

Abdel-Mogheeth et al. (1995), All aquifers (Miocene limestone ,Eocene limestone and dolomite, lower Cretaceous sandstone) in Siwa oasis are under artesian head and their waters are naturally flowing. The upward leakage from the deeper sandstone aquifer to the shallower carbonate one is still not proved.

Geographical Information Systems (GIS) have proved to be immensely helpful in the organization of the huge database generated through space technology (Bolstad, 2005). The utility of GIS in the analysis and modeling of integrated information is well established (Buzai and Robinson, 2010). GIS has been used in the development of digital databases, assessment of status and trends of resources utilization of the areas and to support and assess various resource management alternatives (Harvey, 2008). Spectacular developments in the field of GIS to synthesize various thematic information with collateral data have not only made this technology effective and 
Thabet, M. A. et al.

economical but also a tool to arrive at development strategies for sustainable land and water resources management.

Farmers can order spectral imagery of their fields to determine the status of their land and whatever is growing on it. For example, spectral imagery can indicate the amount of fertilization required in specific locations that are designated with GPS coordinates. Agricultural machinery on the market today has the capability to load this information into computers built into the machinery and automatically adjust the amount of fertilizer deposited based on the information contained in the spectral imagery. The type of vegetation can also be determined from spectral remote sensing. ( Elangovan, 2006) shows the types of plants growing in a field. Because stressed vegetation looks different from healthy vegetation, mapped remote.

\section{MATRIALS AND METHODS}

\section{Physiographic mapping}

Physiographic map produced for the study area was carried out using digital image processing of Landsat7 ETM+ image, dated to 2005 (map. 2). This image was executed using ENVI 5.0 software (ITT 2012). Digital elevation model (DEM) of the studied area is used for driven Physiographic mapping units. Satellite image was stretched using linear $2 \%$, smoothly filtered and their histograms were matched according to Lille sand and Kiefer (2007). The image was atmospherically corrected using; FLAASH module (ITT 2012). The different landforms were initially determined and delimited from the satellite image and the digital elevation model extracted from the contour map, following the methodology developed by Dobos et al. (2002) map (2) and Table (1).

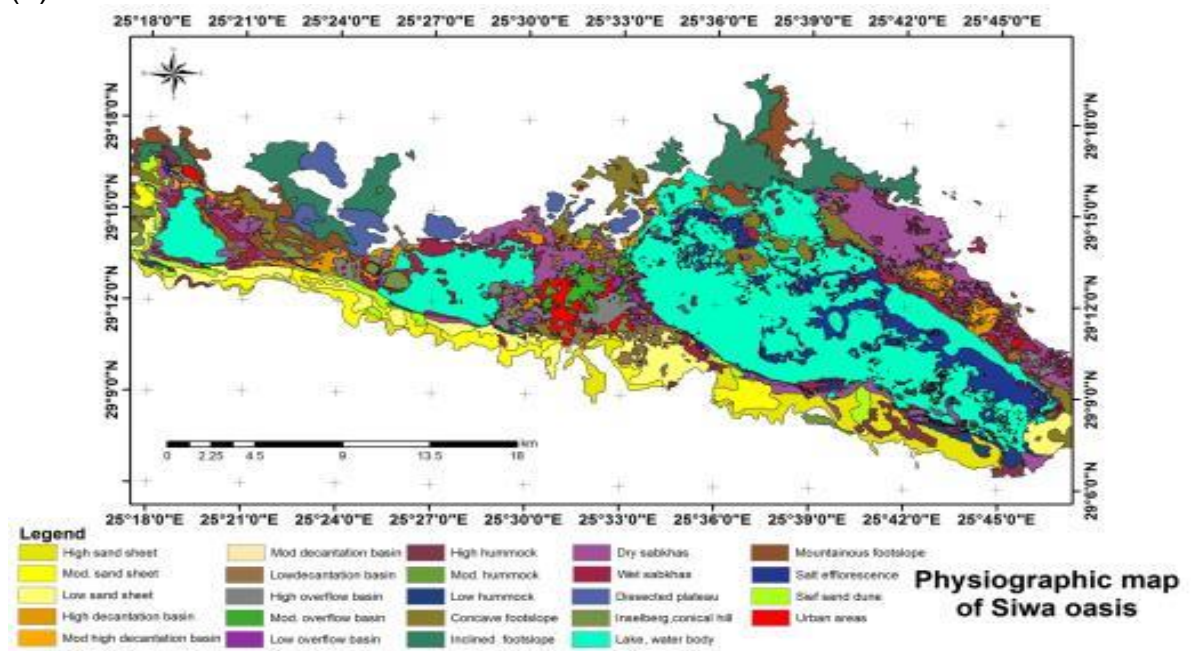

Map (2) Physiographic map of the stuided area. 
J. Soil Sci. and Agric. Eng., Mansoura Univ., Vol. 4 (8), August, 2013

Table (1): Physiographic map legend of the stuided area .

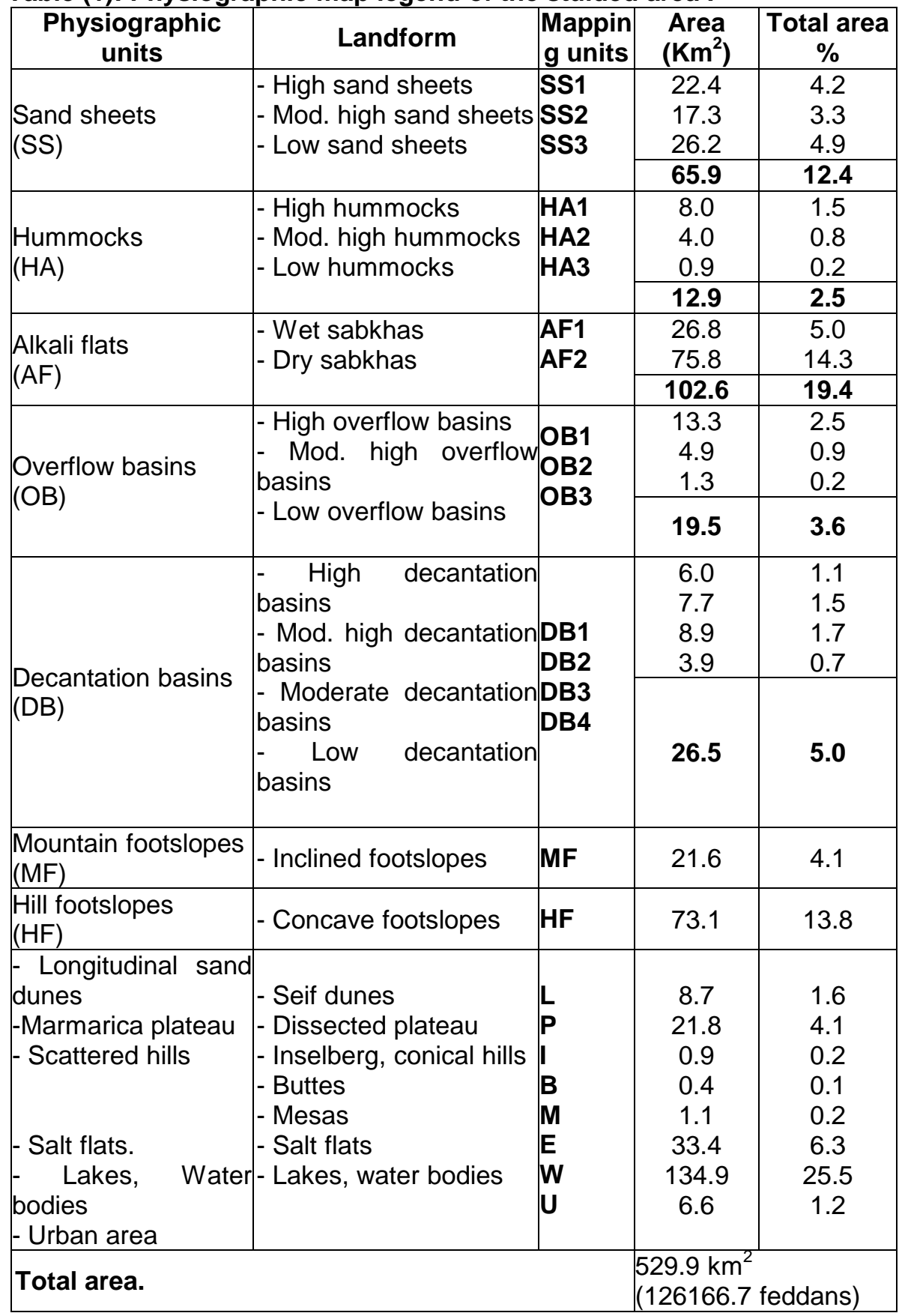


Thabet, M. A. et al.

Physiographic map unit's representative by 17 soil profiles and 100 soil observation to check unit boundaries map (3) and Table (2).

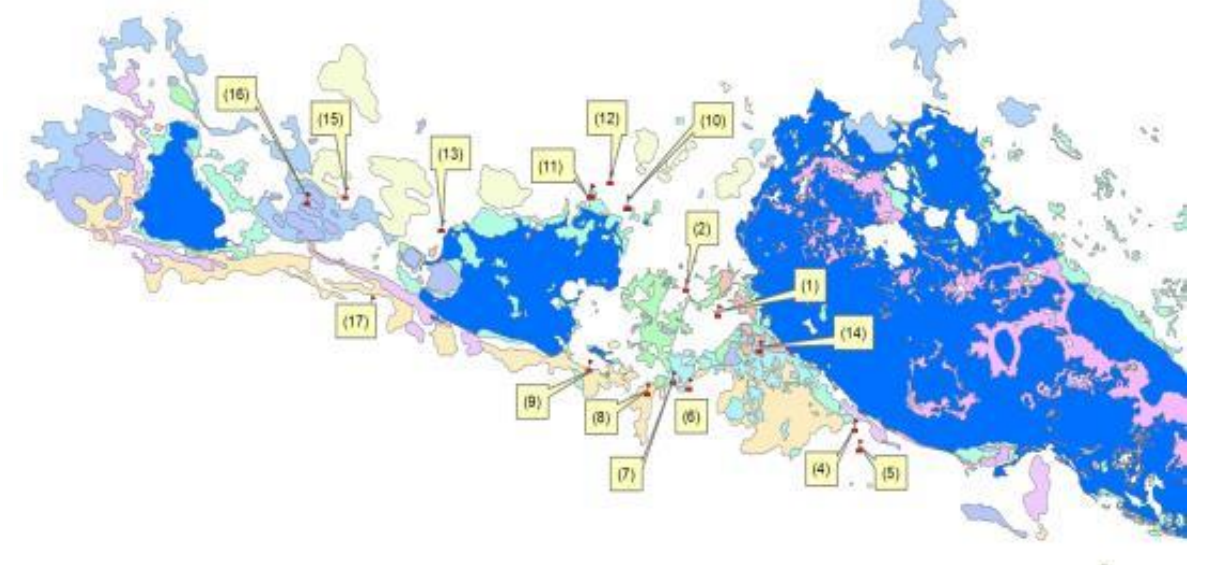

Map(3) Physiographic map of soil profiles location.

Table (2): soil profiles location(Lat.\& Long.).

\begin{tabular}{|c|c|l|c|c|}
\hline ID & pr.dpth & \multicolumn{1}{|c|}{ physiography } & Lat. & Long. \\
\hline 1 & 120 & High overflow & 291206.91 & 253243.42 \\
\hline 2 & 100 & Mod. Overflow & 291236.43 & 253154.87 \\
\hline 3 & 60 & Low overflow bas & 291234.97 & 293247.19 \\
\hline 4 & 150 & High hummock & 290955.09 & 253608.85 \\
\hline 5 & 150 & High sand sh & 290931.40 & 253615.42 \\
\hline 6 & 100 & Mod. hummock & 291040.76 & 253201.15 \\
\hline 7 & 50 & Low decantation & 291048.42 & 253137.24 \\
\hline 8 & 60 & Low sand sheet & 291033.99 & 253059.24 \\
\hline 9 & 80 & Low hummock & 291100.63 & 252931.87 \\
\hline 10 & 150 & High decant & 291415.72 & 253024.10 \\
\hline 11 & 50 & Wet sabkha & 291428.56 & 252933.91 \\
\hline 12 & 80 & Dry sabkhas & 291440.63 & 253000.13 \\
\hline 13 & 100 & Mod high decan & 291342.12 & 252549.15 \\
\hline 14 & 150 & Mod. sand sh & 291126.16 & 253345.91 \\
\hline 15 & 40 & Concave foots & 291419.25 & 252325.25 \\
\hline 16 & 25 & Inclined footsl & 291411.10 & 252228.42 \\
\hline 17 & 80 & Mod decantation & 291211.57 & 252406.86 \\
\hline
\end{tabular}

Field work:-

Soil profile study:-Detailed morphological description of 17 soil profiles representing the different physiographic map units was recorded on the basis outlined by FAO (2010), and Mensal color charts . A total of 52 disturbed soil samples were collected for determining different soil properties. 


\section{Laboratory analyses:-}

The collected disturbed soil samples were air-dried; ground gently, then sieved through $2 \mathrm{~mm}$ sieve and gravel content were calculated. The soil samples were mechanically analyzed according to the international method using Sodium Hexameter phosphate as a dispersing agent (to calculate texture class). Calcium carbonate, Organic matter, Electric conductivity EC $\mathrm{dS} / \mathrm{m}$, Soil reaction $(\mathrm{pH})$ in soil paste, Gypsum content, Caution exchange capacity (CEC), Exchangeable sodium, Available nitrogen, Available phosphorus, Available potassium, were determined according to (Black,1982 and 1986).

Keys to Soil Taxonomy (USDA 1999) were used to classify the different soil profiles according to the morphological description of the investigated profiles and the data extracted. Arc GIS 10.1 utility and its spatial analyst extension (ESRI 2012) were used for soil mapping, land capability and land suitability mapping. Land capability determined according to Require (1970), FAO (1976), El-Toukhy (1995), and Arc GIS 10.1 , Land suitability assessment by ASEL program according to (Ismail et al. 1994).

In this research, ASEL-GIS model was used for land assessment and comparison purposes. It stands for the Agriculture Land Evaluation System for arid and semi-arid regions and has been developed by Ismail et al (2005). The land suitability indices, classes, and limitations for 13 crops were calculated by matching the standard crop requirements (internal coded data within the model) and various soil parameter levels (FAO 1976; Ismail et al. 1994, 2001). Nevertheless, ASEL was linked directly to its relational database and coupled indirectly with a GIS through the loosely coupled strategy. Using land suitability analysis based on GIS utility, site information can be gained. It is considered as strong and efficient application within land use planning, habitat analysis, etc. (El-Nahry and Khashaba 2006).

\section{RESULTS AND DISCUSSION}

This current study deals with the current land in order to assess land suitability for main strategic crops. The presentation and discussions will be grouped under the following headings:

5.1 The main physiographic unites of Siwa oasis.

5.2 Soil mapping and Taxonomy.

5.3 Land capability

5.4 Land suitability classification.

\subsection{The main physiographic unites of Siwa oasis.}

Physiographic units were identified throughout remote sensing image. The obtained results (table 5 and map 5) include the following Physiographic units:

17 Soil profiles representative the physiographic map units of studied area decrypted and collected the soil samples(52) were done. 
Thabet, M. A. et al.

Table (3): Physiographic legend and areas of the different mapping units.

\begin{tabular}{|c|c|c|c|c|}
\hline Physiographic units & Landform & $\begin{array}{l}\text { Mapping } \\
\text { units }\end{array}$ & Area & rotalare \\
\hline \multirow{2}{*}{$\begin{array}{l}\text { Sand sheets } \\
\text { (SS) }\end{array}$} & \multirow{2}{*}{\multicolumn{2}{|c|}{$\begin{array}{l}\text { - High sand sheets } \\
\text { - Mod. high sand SS1 } \\
\text { sheets } \\
\text { - Low sand sheets }\end{array}$}} & $\begin{array}{l}22.4 \\
17.3 \\
26.2\end{array}$ & $\begin{array}{l}4.2 \\
3.3 \\
4.9\end{array}$ \\
\hline & & & 65.9 & 12.4 \\
\hline $\begin{array}{l}\text { Hummocks } \\
(\mathrm{HA})\end{array}$ & $\begin{array}{l}\text { - High hummocks } \\
\text { - Mod. high hummocks } \\
\text { - Low hummocks }\end{array}$ & $\begin{array}{l}\text { HA1 } \\
\text { HA3 }\end{array}$ & $\begin{array}{l}8.0 \\
4.0 \\
0.9 \\
129\end{array}$ & $\begin{array}{l}1.5 \\
0.8 \\
0.2 \\
2.5\end{array}$ \\
\hline $\begin{array}{l}\text { Alkali flats } \\
(A F)\end{array}$ & $\begin{array}{l}\text { - Wet sabkhas } \\
\text { - Dry sabkhas }\end{array}$ & \begin{tabular}{|l} 
AF1 \\
AF2
\end{tabular} & \begin{tabular}{|l}
12.9 \\
26.8 \\
75.8 \\
102.6
\end{tabular} & $\begin{array}{l}2.5 \\
5.0 \\
14.3 \\
19.4\end{array}$ \\
\hline \multirow{2}{*}{$\begin{array}{l}\text { Overflow basins } \\
(\mathrm{OB})\end{array}$} & \multirow{2}{*}{\multicolumn{2}{|c|}{$\begin{array}{l}\text { - High overtlow basins } \\
\text { - Mod. high overflow } \\
\text { basins } \\
\text { - Low overflow basins }\end{array}$}} & \begin{tabular}{|l}
13.3 \\
4.9 \\
1.3 \\
\end{tabular} & $\begin{array}{l}2.5 \\
0.9 \\
0.2\end{array}$ \\
\hline & & & 19.5 & 3.6 \\
\hline \multirow{2}{*}{$\begin{array}{l}\text { Decantation basins } \\
\text { (DB) }\end{array}$} & \multirow{2}{*}{\multicolumn{2}{|c|}{ 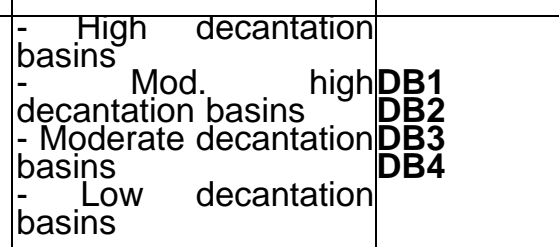 }} & $\begin{array}{l}6.0 \\
7.7 \\
8.9 \\
3.9 \\
\end{array}$ & $\begin{array}{l}1.1 \\
1.5 \\
1.7 \\
0.7\end{array}$ \\
\hline & & & 26.5 & 5.0 \\
\hline \multirow{2}{*}{$\begin{array}{l}\text { Mountain tootslopes } \\
\text { (MF) } \\
\text { Mill footslopes } \\
(H F)\end{array}$} & - Inclined footslopes & MF & 21.6 & 4.1 \\
\hline & - Concave footslopes & HF & 73.1 & 13.8 \\
\hline $\begin{array}{l}\text { dunes } \\
\text {-Marmarica plateau } \\
\text { - Scattered hills } \\
\text { - Salt flats. } \\
\text { - bodies } \\
\text { - Urban area }\end{array}$ & $\begin{array}{l}\text { - Seif dunes } \\
\text { - Dissected plateau } \\
\text { - Inselberg, conical } \\
\text { hills } \\
\text { - Buttes } \\
\text { - Mesas } \\
\text { - Salt flats } \\
\text { - Lakes, water bodies }\end{array}$ & $\mid \begin{array}{l}\mathrm{L} \\
\mathrm{P} \\
\mathrm{B} \\
\mathrm{M} \\
\mathrm{E} \\
\mathbf{W} \\
\mathrm{U}\end{array}$ & $\begin{array}{c}8.7 \\
21.8 \\
0.9 \\
0.4 \\
1.1 \\
33.4 \\
134.9 \\
6.6\end{array}$ & $\begin{array}{l}1.6 \\
4.1 \\
0.2 \\
0.1 \\
0.2 \\
6.3 \\
25.5 \\
1.2\end{array}$ \\
\hline \multicolumn{3}{|l|}{ Total area. } & \multicolumn{2}{|c|}{$\begin{array}{l}529.9 \mathrm{~km} \\
\text { (126166.7 } \\
\text { feddans) }\end{array}$} \\
\hline
\end{tabular}

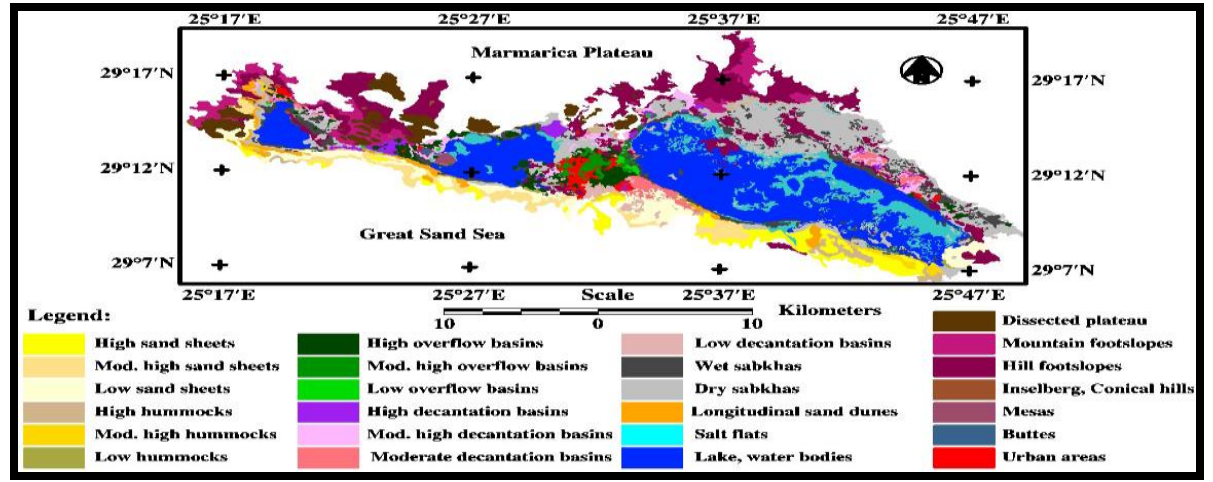

Map (4): Physiographic map of Siwa oasis 
J. Soil Sci. and Agric. Eng., Mansoura Univ., Vol. 4 (8), August, 2013

Table (4) Morphological features of the soil profile description . 
Chemical analysis:- The chemical analysis of the studed area showed in table (4) and maps (5) From table (4) and maps (5) clear that the soil reaction $(\mathrm{pH})$ ranged between 7.4 and 9.3 which could be referred to increased in alkali in some units. $\mathrm{CaCO}_{3}$ content ranged between 10 and $51.4 \%$ except soil profiles $6,9,10,14$, and 17 were less than $10 \%$ which could be referred to the calcareous sediments of parent material. gypsum content were less than one in the dominant profiles excepted soil profiles $5,10,11$, and12 ranged between 1.59 and $5.04 \%$. O.M\% values are less than one except in profiles $2,3,5,6,11,12$, and 14 are ranged between 1.01 and $2.6 \%$. EC $(\mathrm{dS} / \mathrm{m})$ values are ranged between moderate and high as 2.6 and 98.3 which could be referred to the ground water is near from the surface and parent material except soil profiles 3, 4, 5, 6 are low than $2 \mathrm{dS} / \mathrm{m}$. Available values of Nitrogen (ppm) ranged between 5.5 and 22.4 (ppm) which refereed to decrease organic matter. Available of phosphorus values ranged between 2.8 and $20.8(\mathrm{ppm})$ which refereed to fixate by parent material. Available values ranged between 186.6 and 606.8 (ppm).

Table(5) The chemical analysis of the investgated area.

\begin{tabular}{|c|c|c|c|c|c|c|c|c|c|c|}
\hline D & $\mathrm{pH}$ & CEC & (dS/ & $\mathrm{CaCO}_{3}$ & ESP & Gyp & D.M\% & $\mathrm{V}(\mathrm{ppm}$ & $\mathrm{P}(\mathrm{ppm}$ & $\mathrm{K}(\mathrm{pp}$ \\
\hline & & & & & & $\%$ & & & & \\
\hline 1 & 8 & 13.6 & 12.1 & .4 & 13.2 & & 0.8 & 1.1 & 51.8 & 8 \\
\hline 2 & .1 & 26.4 & 8 & 1.79 & 6.3 & & 1.3 & & 04 & \\
\hline 3 & 9 & 9.3 & 4 & .9 & & & 1.1 & 12 & 30.8 & \\
\hline 4 & 3 & 2.7 & .5 & 1.44 & 9.2 & & 0.1 & 11. & 11.1 & 18.7 \\
\hline 5 & \begin{tabular}{l|l|}
8.8 \\
\end{tabular} & 19 & 6 & 0.7 & 15.4 & & 1.01 & & 47.3 & \\
\hline 6 & 8.3 & 3.3 & & )3 & 29.7 & & 2.6 & & 33 & 351.5 \\
\hline 7 & 9.3 & 20.2 & & & 27.6 & & 0.29 & & 8 & \\
\hline 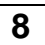 & 8 & 14.9 & 42 & 11.6 & 11.1 & & 0 & & 4 & .2 \\
\hline 9 & 8.3 & 4.1 & 03 & & & & 0.2 & 4 & 1.5 & .1 \\
\hline 10 & 8.5 & 5.7 & & 1. & 6.6 & & 0.1 & 2 & 0.1 & \\
\hline 11 & 8.1 & 21.4 & & .4 & 36.4 & & 2.6 & 2 & 3.6 & \\
\hline 12 & 7.8 & 35.1 & & 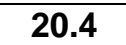 & 34.8 & & 2.4 & & 5.3 & 82.6 \\
\hline 13 & 8.3 & 4.7 & & ?.3 & 23.7 & & 0.2 & & 55.9 & \\
\hline 14 & 7.9 & 30.1 & & & 17 & & 2.05 & & 2.8 & \\
\hline & 3.1 & & & 11 & & & 0.2 & & 17.4 & \\
\hline 16 & 8.4 & 4.9 & & .6 & 12.3 & & 0.6 & & 4.8 & .8 \\
\hline 17 & 7.4 & 4 & 8.3 & 1.6 & 12.5 & 0.007 & 0.1 & 20.5 & 9.1 & 525.6 \\
\hline
\end{tabular}


J. Soil Sci. and Agric. Eng., Mansoura Univ., Vol. 4 (8), August, 2013

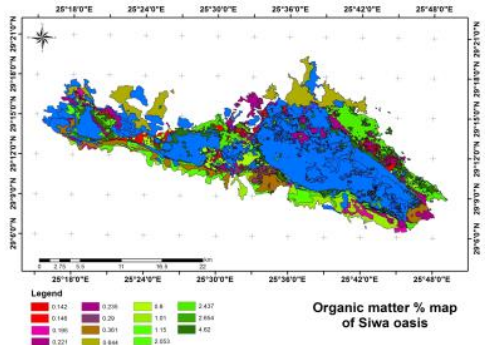

Map (5:A)

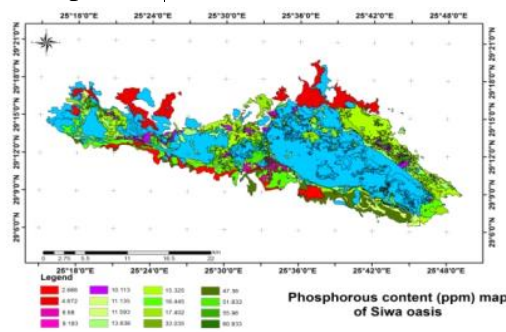

Map (5:C)
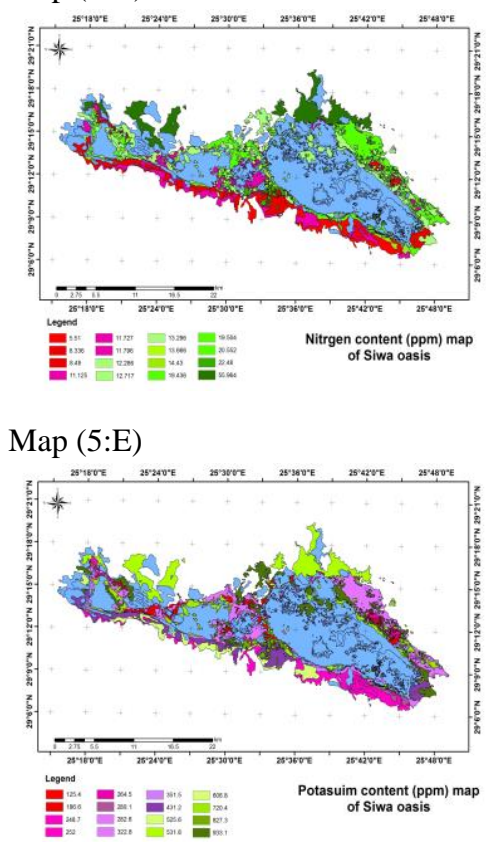

$\operatorname{Map}(5: G)$

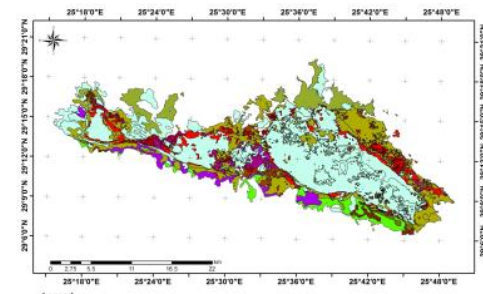

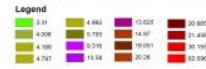

Map (5:B)

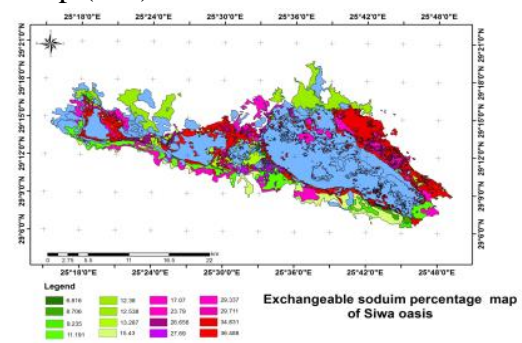

Map (5:D)

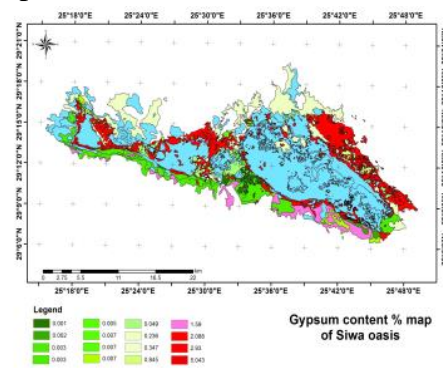

Map (5:F)

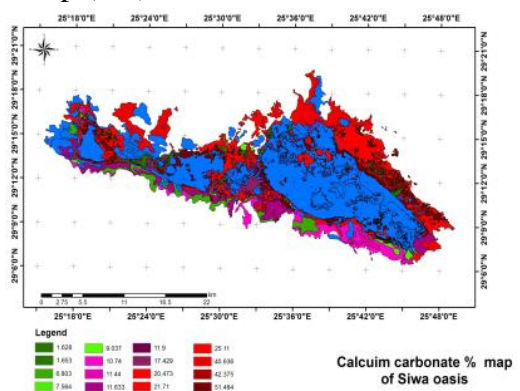

$\operatorname{Map}(5: \mathrm{H})$

Map (5) The chemical analysis of the investigated area. 
Thabet, M. A. et al.

\section{Soil map:-}

Final description of each map unit is prepared. Soil properties and soil interpretation tables are completed to confirm with the mapping units shown on the final soil map as shown in text. Based on the (USADA, 2010) Soil classification the soils of the area classified as following:- Typic Torripsamments, Typic Psammaquents, Typic Haplosalids, Typic Aquisalids, Gypsic Haplosalids, Calcic Aquisalids, Typic Haplocalcids, Lithic Haplocalcids, and Duric Haplosalids; and map (6)

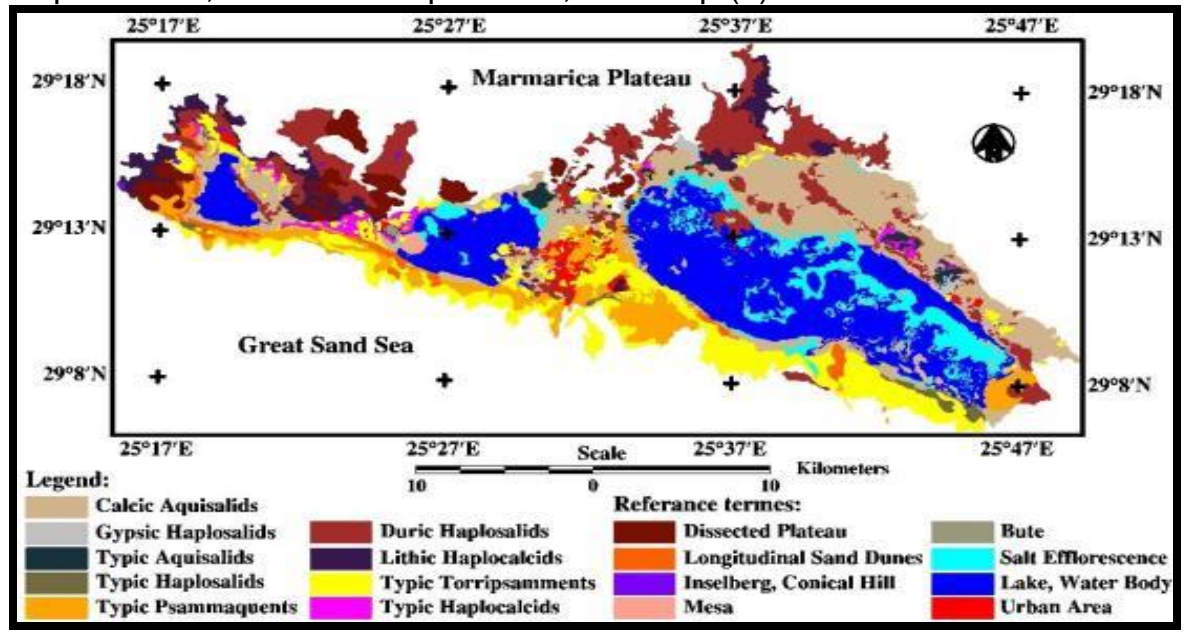

Map(6)

\section{Land Capability:-}

Soil capability map produced ; based on the soil properties and using Require (1970), FAO (1976), El-Toukhy (1995), and Arc GIS 10.1, The soils of Siwa oasis are Good, Average, Low, Extremely low; and Map ( 7 )

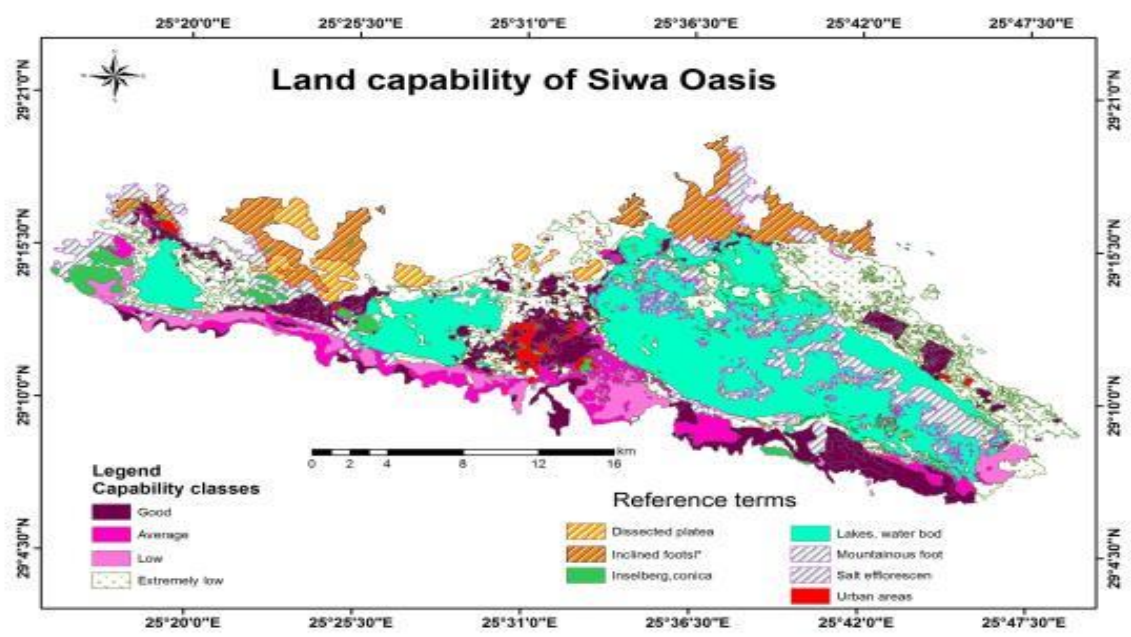

Map(7) land capability of the study area 
Land Suitability:-

Soil suitability map produced by using ASLE and Arc GIS 10.1

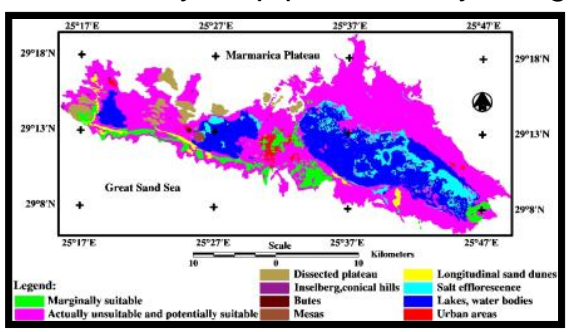

Map (8) Suitability for onion.

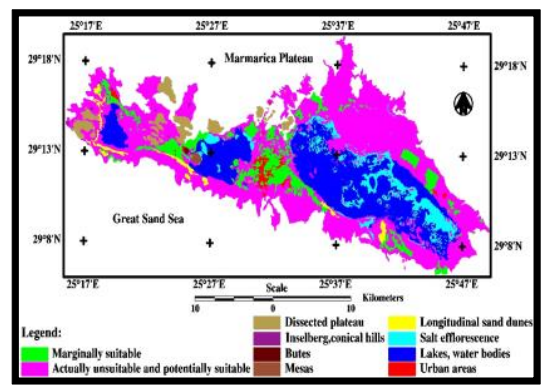

Map (10)Suitability for barley.

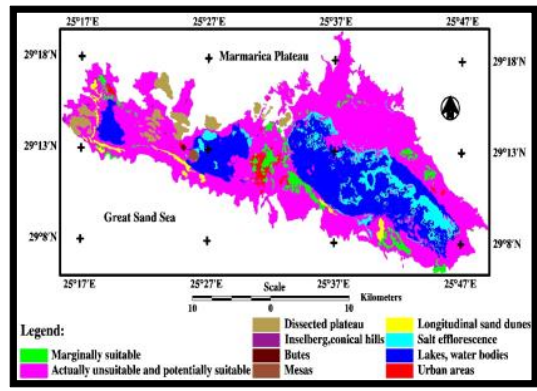

Map (12)Suitability sugar cane.

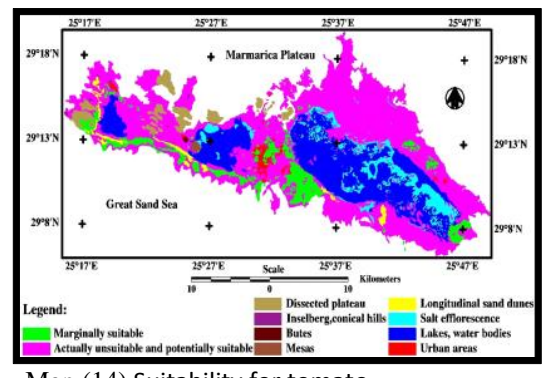

Map (14) Suitability for tomato.

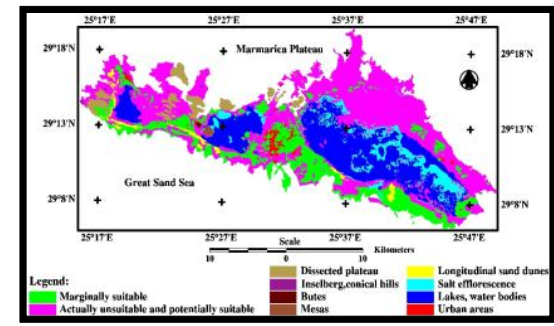

Map (9) Suitability for alfalfa.

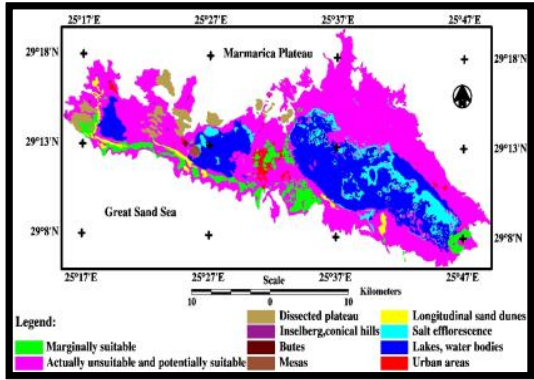

Map (11)Suitability for green pepper.

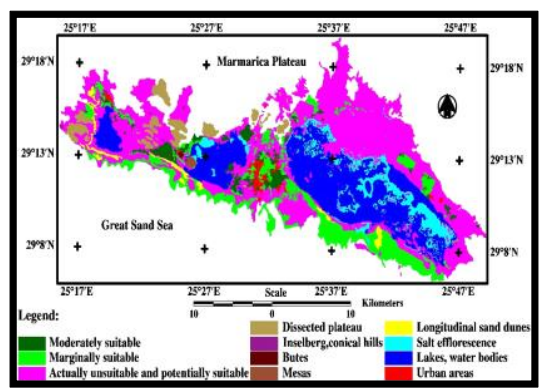

Map (13) Suitability for olives.

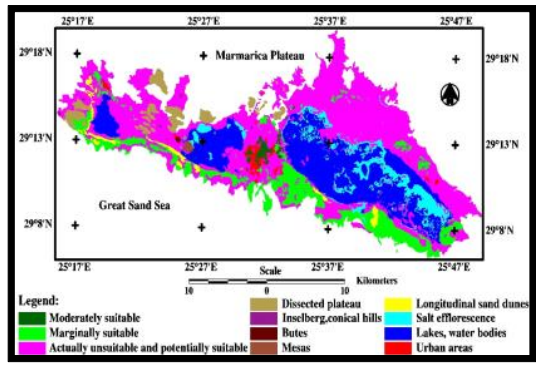

Map (15) Suitability for maize. 


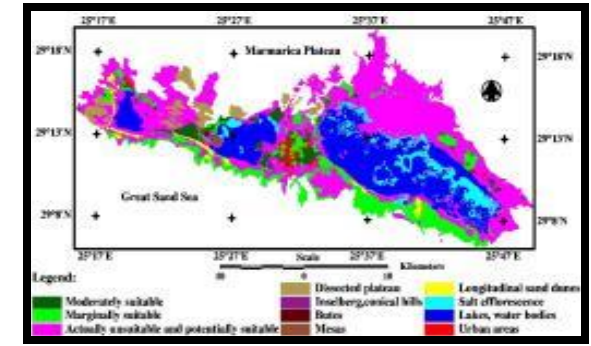

Map (16) Suitability for wheat.

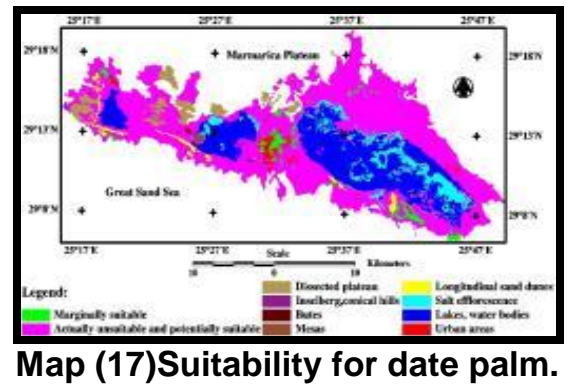

According ASEL program the soil suitability of Siwa oasis for alfalfa, green pepper, onion, olives, maize, barley, sugar cane, tomato, wheat, date palm, and wheat ranged between marginal and unsuitable.

\section{CONCLUSION}

Siwa oasis is a narrow depression located in the west of the western Egyptian desert, approximately $300 \mathrm{~km}$ south from the Mediterranean coast in correspondence south of the city of Marsa Matruh between longitudes, $25^{\circ}$ $16^{\circ}-26^{\circ} 7^{\circ} \mathrm{E}$ and latitudes, $29^{\circ} 7^{\circ}-29^{\circ} 21^{\circ} \mathrm{N}$. It extended for about $70 \mathrm{~km}$ in eastwest direction, with a width of $7-10 \mathrm{~km}$. The total area of Siwa Oasis about $2,950 \mathrm{sq} . \mathrm{km}$ representing the ideal continuation towards west of the larger depression of Qattara. This area has always been confined as a possible area for reclamation and utilization due to its location and the presence of ground water in a suitable quality for irrigation. The dominant texture class varied from sand, loamy sand, sandy loam ; and silty loam From table (4) and maps (5) clear that the soil reaction $(\mathrm{pH})$ ranged between 7.4 and 9.3 which could be referred to increased in alkali in some units. $\mathrm{CaCO}_{3}$ content ranged between 10 and $51.4 \%$ except soil profiles $6,9,10,14$, and 17 were less than $10 \%$ which could be referred to the calcareous sediments of parent material. gypsum content were less than one in the dominant profiles excepted soil profiles 5, 10, 11, and12 ranged between 1.59 and $5.04 \%$. O.M\% values are less than one except in profiles $2,3,5,6,11,12$, and 14 are ranged between 1.01 and $2.6 \%$. EC $(\mathrm{dS} / \mathrm{m})$ values are ranged between moderate and high as 2.6 and 98.3 which could be referred to the ground water is near from the surface and parent material except soil profiles 3, 4, 5, 6 are low than $2 \mathrm{dS} / \mathrm{m}$. Available values of Nitrogen (ppm) ranged between 5.5 and $22.4(\mathrm{ppm})$ which refereed to decrease organic matter. Available of phosphorus values ranged between 2.8 and 20.8 (ppm) which refereed to fixate by parent material. Available values ranged between 186.6 and 606.8 (ppm). Keys to Soil Taxonomy (USDA 1999) were used to classify the different soil profiles according to the morphological description of the investigated soil profiles and the data extracted. Arc GIS 10.1 utility and its spatial analyst extension (ESRI 2012) Basied (USDA 1999) the soils of the area under investigated classified as Typic Torripsamments, Typic Psammaquents, Typic Haplosalids, Typic Aquisalids, Gypsic Haplosalids, 
Calcic Aquisalids, Typic Haplocalcids, Lithic Haplocalcids, and Duric Haplosalids. According to the morphological description of the investigated soil profiles and the data extracted. Arc GIS 10.1 utility and its spatial analyst extension (ESRI 2012) based on require (1970) …..... the soil capability of the investigated area varied from Good, Average, Low ,and Extremely low which refried to the problems in the soil properties as soil parent material, soil depth soil texture, EC ,ESP , water table depth. According to the morphological description of the investigated soil profiles and the data extracted. Arc GIS 10.1 utility and its spatial analyst extension (ESRI 2012) Based on ASSEL program the soil suitability of the investigated area for alfalfa, green pepper, onion, maize, barley, sugar cane, tomato, wheat, and wheat ranged between marginal and unsuitable except olives, and date palm, ranged between moderate and unsuitable which could be referred to problems in the soil properties, climate of the area and the soil management.

\section{REFERENCES}

Abu Al-Izz, M.S. (1999) "Geography of Egypt". El-Nahda Press, Cairo, Egypt (in Arabic).

Abdel-Mogheeth, S.M.; El-Hakeem, M.S.; and Afifi, M.Y.(1995) "Wetlands management for sustainable development in Siwa oasis, Egypt". Versatility of wetland in the agricultural landscape, Pub., American Society of Agricultural Engineers, Sept 17-20, 1995, Ed. Kenneth L.C ampbell, pp.745- 755 .

Abd El-Samie, M.K.A. (2000). Classification and evaluation of Siwa oasis soils. Ph.D. Thesis, Fac. Agric., Ain Shams Univ.

Abo-Ragab, Samy al said aly (2008). Water Management of the Siwa Oasis, Western Desert, Egypt, The 33rd International conference for statistics, Computer Science And It's Applications 6-17 April, p198 223.

Black, C. A. (1965). "Methods of soil analysis". Agron. Series, No. 9, Am. Soc. Agron., Inc. Madison, Wisconsin, USA.

Black C.A, (ed) (1982). "methods of soil analysis. Part2, chemical and microbiological properties " Agronomy series no. 9,ASA,SSSA, madison, Wis., USA1982.

Black C.A. (ed) (1986). "methods of soil analysis. Part1, physical and microbiological properties " second (ed). Agronomy series no. 9,ASA,SSSA, madison, Wis., USA1982.

Bolstad, P. (2005). GIS Fundamentals: A first text on Geographic Information Systems, Second Edition. White Bear Lake, MN: Eider Press, 543 pp.

Buzai, G.D. and Robinson, D. (2010). Geographical Information Systems in Latin America, 1987-2010. A Preliminary Overview. Journal of Latin American Geography. 9(3):9-31.

Climatologically Normal for Egypt (2011), the normal for Dakahlia governorate station, $(1960-2011)$, Ministry of civil Aviation: meteorological Authority, Cairo, Egypt. 
Dobos E, Norman B, Bruee W, Luca M, Chris J, Erika M (2002). The use of DEM and satellite images for regional scale soil database. Proceedings of the 17th World Congress of Soil Science, August 4-21, 2002, Bangkok, Thailand

Elangovan,K (2006) "GIS: Fundamentals, Applications and Implementations", New India Publishing Agency, New Delhi"208 pp.

El-Nahry AH, Khashaba HE (2006) Land suitability modeling of natural vegetation using integrated remote sensing and GIS tech- niques: a case study. J Applied Sci 6(1):51-56

ESRI (2012) Arc map version 9.3.1 user manual, ESRI: ESRI product,California, USA

El- Toukhy, M. M. A., (1995). Studies on land evalu Fanous, N. E. (1979) "Mineralogical studies of some soils of Siwa". M.Sc., Thesis, Fac. Agric., Cairo Univ., Egypt.

FAO, (1976) "A framework for land evaluation". Soils Bulletin No. 32. FAO, Rome, Italy.

FAO (2010). "Guidelines to soil profile description", FAO publicatios, Rome.

Harvey, F. (2008) A Primer of GIS, Fundamental geographic and cartographic concepts. The Guilford Press, $31 \mathrm{pp}$.

ITT, 2012. ITT corporation ENVI 5.0 software, 1133 Westchester Avenue, White Plains, NY 10604, USA

ITT (2012) ITT Corporation ENVI 5.0 software. White Plains, NY, USA Klute A (1986) Methods of soil analysis, part I. Physical and mineralog-ical methods, 2nd edn. ASA and SSSA, Madison, p 1189

Ismail HA, El-Zahaby EM, El-Fayoumy ME (1994) A modify ap- proach for land evaluation under arid condition. Applications. Mansoura Univ $\mathrm{J}$ Agric Sci 19:3497-3513

Ismail HA, Morsy I, El-Zahaby EM, El-Nagar FS (2001) A developed expert system for land use planning by coupling land information system and modeling. Alexandria J Agric Res 46:141-154

Ismail HA, Bahnass MH, Abd El-Kawy OR (2005) Integrating GIS and modelling for agricultural land suitability evaluation at East Wadi ElNatrun, Egypt. Egyptian J Soil Sci 45:297-322

Lillesand TM, Kiefer RW (2007) Remote sensing and image interpre- tation, 5th edn. John Wiley and Sons, New York, p 820, ISBN-13: 9788126513352

Omran, A.M.El-Sa. (2002). Pedogenesis and mineralogy of soils in Siwa oasis, Egypt. M.Sc. Thesis, Fac. Agric., Minufia, Univ., Egypt.

Said, R. (1993). "The river Nile geology and hydrology and utilization". Oxford. Britain. Pergman press $320 \mathrm{p}$.

Said, R. (2000) "The Geology of Egypt". El-Sevier Pub., Comp., Amsterdam.

Sherif, M. A. M. (1979) "Evaluation for fertility status in soils of Siwa oasis". M.Sc. Thesis, Fac. Agric., Ain shams Univ., Egypt. 
USDA (1999) "Soil Taxonomy". A basic system of soil classification for making and interpreting surveys, Second Edition, United States Department of agriculture (USDA), Agriculture Handbook, No. 436, Washington, D.C., USA.

USDA, 2010. Keys to Soil Taxonomy. United State Department of Agriculture, Natural Resources Conservation Service (NRCS) eleventh edition.

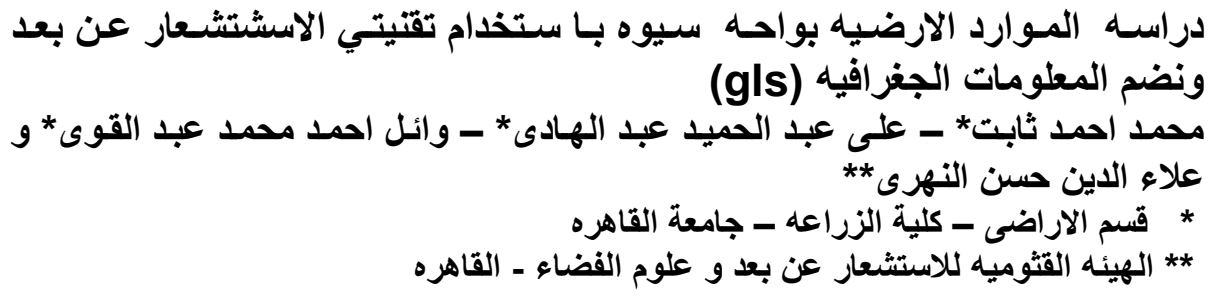

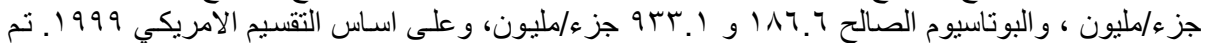
تقسيم اراضي المنطقة الىى Typic Torripsamments, Typic Psammaquents, Typic Haplosalids, Typic Aquisalids, Gypsic Haplosalids, Calcic Aquisalids, Typic و على اساس الخواص Haplocalcids, Lithic Haplocalcids, and Duric Haplosalids. After Require (1970), FAO (1976), El-Toukhy (1995), Arc GIS الارضية تبعاً لنظام 10.1. اساس نظام ASLE and Arc GIS 10.1 تم تقسيم الارض حسب صساحيتها للمحاصيل حيث نجد marginal and unsuitable for alfalfa, green pepper, onion, صلاحيتها تتراوح بين maize, barley, sugar cane, tomato, wheat, بين متوسط و عديم الصلاحية.

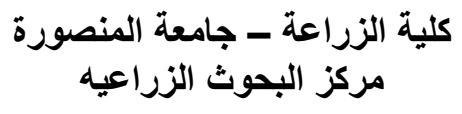

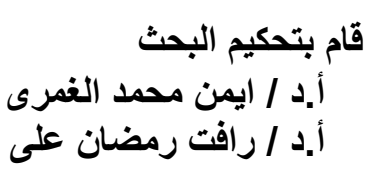

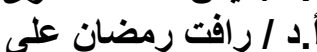

